\title{
KAJIAN PENGGUNAAN LAHAN DI SEKITAR KAWASAN BUKIT SEMARANG BARU
}

\section{STUDY ON LAND USE AROUND BUKIT SEMARANG BARU AREA}

Nadia Oktinova', Iwan Rudiarto

${ }^{1}$ Kementerian Agraria dan Tata Ruang/Badan Pertanahan Nasional, Kanwil BPN Provinsi Nusa Tenggara Barat; Mataram; nadiaoktinova@gmail.com

²Departemen Perencanaan Wilayah dan Kota, Universitas Diponegoro; Semarang; irudiarto@yahoo.com

\section{Info Artikel:}

- Artikel Masuk: 25 Desember 2018

- Artikel diterima: 22 November 2019

- Tersedia Online: 31 Desember 2019

\begin{abstract}
ABSTRAK
Jumlah penduduk di pusat kota yang cukup besar mengakibatkan semakin berkurangnya lahan di wilayah tersebut sehingga lambat laun akan terjadi perkembangan perkotaan ke arah pinggiran (urbanisasi), seperti yang terjadi di Kota Semarang yaitu pengembangan kota baru Bukit Semarang Baru (BSB) di Kecamatan Mijen. Dengan adanya BSB ini terjadi perubahan penggunaan lahan yang kemudian juga mengakibatkan adanya perkembangan perkotaan di sekitarnya. Dengan adanya hal tersebut, penelitian ini bertujuan untuk menganalisis perubahan penggunaan lahan dan perkembangan perkotaan yang terjadi di sekitar kawasan BSB. Pendekatan penelitian ini yaitu pendekatan kuantitatif dengan pendekatan spasial yang pengolahan data serta analisisnya secara spasial menggunakan software ArcGIS 10.3.1. Data penggunaan lahan diperoleh dengan interpretasi citra DigitalGlobe tahun 2013 dan tahun 2017 yang kemudian dilakukan teknik overlay untuk mengetahui perubahan penggunaan lahannya. Hasil dari penelitian ini yaitu telah terjadi perubahan penggunaan lahan dari lahan pertanian menjadi danau/waduk (36,45 ha), industri (14,98 ha), lahan kosong (22,41 ha), perdagangan dan jasa (2,78 ha) dan permukiman $(84,84 \mathrm{ha})$ serta perubahan penggunaan lahan permukiman menjadi perdagangan dan jasa (2,59 ha). Di sekitar kawasan BSB juga telah terjadi perkembangan perkotaan yang terlihat dari peningkatan penggunaan lahan terbangun sebesar 102,59 ha dengan pola konsentris dan horisontal dimana lahan terbangunnya ini menyebar pada seluruh wilayahnya.
\end{abstract}

Kata Kunci : Urbanisasi; Penggunaan Lahan; Perkembangan Perkotaan; Kota Baru

\begin{abstract}
The big population in city center may result in reduced the amount of the land in that area which will affect the urban development in the suburban, or well known as an urbanization. This happened in Mijen district that located in Semarang City, where they developed a new city called "Bukit Semarang Baru" (BSB) which resulted in the land use change and developments in the surrounding area of urban development. With that case, the objective of the research is to analyzing change in the land use and the effect for the surrounding urban development in BSB area. This research uses quantitative and spatial approach using ArcGIS 10.3.1. software for calculating and analyzing the data. Data of the land use is retrieved from DigitalGlobe image in 2013 and 2017. The researcher uses overlay technique for knowing the changing of the land use. The result of this research that has been changing land use from agricultural land into Lake/reservoir ( $36.45 \mathrm{ha})$, industrial (14.98 hectare), empty land (22.41 ha), trading and services ( $2.78 \mathrm{ha}$ ) and settlement ( $84.84 \mathrm{ha}$ ). It also changes in land use from the settlement into a trading and services (2.59 ha). Surrounding of the BSB area has been occurred urban development, it can be seen from increasing land use 102,59 ha with concentric and horizontal pattern which all of the land use is spread on the whole territory.
\end{abstract}

Kata Kunci : Urbanization; Land Use; Urban Development; New City

Copyright $\odot 2019$ JPWK-UNDIP 


\section{PENDAHULUAN}

Peningkatan jumlah penduduk tanpa diiringi peningkatan ketersediaan lahan telah memicu terjadinya urbanisasi yaitu perkembangan perkotaan ke arah pinggiran. Menurut Champion (2001) ubanisasi sendiri terlihat dari meningkatnya konsentrasi penduduk pada suatu kota, meningkatnya konsentrasi penduduk kota sehingga menjadi kota besar dan meningkatnya konsentrasi penduduk pada suatu pusat pertumbuhan yang kemudian mengarah ke wilayah sekitarnya. Urbanisasi mulai tumbuh dari pusat-pusat perkotaan yang kemudiaan mempengaruhi kawasan pedesaan (Burgess, 1925; Mann, 1965; Bryant et al., 1982 dalam Antrop, 2004).

Urbanisasi berdampak pada peningkatan kebutuhan akan lahan untuk menampung berbagai aktivitas penduduk. Lahan mempunyai peranan penting dalam perekonomian dan pembangunan karena setiap aktivitas manusia memerlukan lahan sebagai ruang, sehingga dalam perencanaan pembangunan diperlukan perhatian yang lebih dalam menangani permasalahan lahan baik dalam pengendalian, penggunaan, penguasaan, pemilikan dan peralihan hak atas lahan yang menghambat pembangunan (Adisasmita, 2014). Lahan sebagai unsur ruang mempunyai makna yang sangat strategis karena di dalamnya terkandung tidak saja aspek fisik akan tetapi juga aspek sosial, ekonomi, budaya bahkan politik, serta pertahanan dan keamanan (Chofyan, 1997 dalam Santoso, 2005).

Menurut Jayadinata (1999) dalam Aryany \& Pradoto (2014) penggunaan lahan akan dipengaruhi segala sesuatu yang berkaitan dengan aktifitas sosial, ekonomi dan kepentingan penduduk yang ada di dalamnya. Chapin \& Kaiser (1979) dalam bukunya yang berjudul Urban Land Use Planning menjelaskan penggunaan lahan dikelompokkan berdasarkan jenis aktivitas yang meliputi:

a. Aktivitas ekstraksi, misalnya pertanian, kehutanan, perikanan, pertambangan dan sebagainya.

b. Aktivitas pengolahan, misalnya industri makanan, tembakau, tekstil, kertas dan sebagainya.

c. Aktivitas transportasi, komunikasi dan utilitas, misalnya transportasi kereta api, transportasi penduduk lokal, jalan raya serta berbagai fasilitas pendukungnya.

d. Aktivitas distribusi, misalnya perdagangan grosir, perdagangan eceran dan sebagainya.

e. Aktivitas pelayanan jasa, misalnya keuangan (bank, asuransi, koperasi, dan sebagainya), pelayanan pribadi, hotel dan motel, bengkel dan sebagainya.

f. Aktivitas rekreasi, pelayanan dan kesejahteraan masyarakat serta rekreasi, misalnya pendidikan, tempat rekreasi, tempat ibadah, rumah sakit, kantor pemerintahan dan sebagainya.

g. Aktivitas pemukiman

h. Tidak ada aktivitas atau lahan tidak terpakai.

Dalam perkembangannya, Godschalk (1988) dalam Kaiser, et al. (1995) juga telah mengklasifikasikan penggunaan lahan yaitu lahan perkotaan (permukiman; komersial dan pelayanan; industri; transportasi, komunikasi dan utilitas; pelayanan masyarakat dan institusi), pertanian, hutan, perairan, lahan basah dan lahan tandus). Klasifikasi penggunaan lahan lainnya juga diungkapkan oleh Nasucha (1995) yaitu: permukiman, perdagangan dan industri; pertanian, lahan holtikultura (padang ternak dan hutan) serta lahan khusus (pertambangan, rekreasi, transportasi dan areal pelayanan).

Perencanaan penggunaan lahan sangat dipengaruhi oleh manusia, aktifitas dan lokasi dimana ketiganya memiliki hubungan keterkaitan antara yang satu dengan yang lainnya, yang dalam siklusnya akan berpengaruh dalam perubahan penggunaan lahan (Catanese, 1986 dalam Aryany \& Pradoto, 2014). Perubahan penggunaan lahan tersebut dipengaruhi oleh pembangunan ekonomi serta perubahan lingkungan dan sosial yaitu dengan peningkatan industrialisasi, urbanisasi, pertumbuhan jumlah penduduk dan reformasi ekonomi (Gu et al, 2016). Pada kenyataannya urbanisasi akan mempengaruhi perubahan penggunaan lahan melalui transformasi hubungan perkotaan-pedesaan (Lambin et al, 2001). Gaya hidup perkotaan yang cenderung konsumtif dan berdasar data dari United Population Fund (1991) dimana penduduk perkotaan pada tahun 2025 meningkat menjadi 60\% nampaknya harus menjadi perhatian yang lebih terhadap keberlanjutan ekologi.

Fenomena perubahan penggunaan lahan merupakan bagian dari transformasi struktur ekonomi sosial dimana pertumbuhan ekonomi dan penduduk yang terpusat pada perkotaan nantinya akan 
membutuhkan ruang yang lebih luas ke arah pinggiran kota baik untuk berbagai aktivitas ekonomi maupun permukiman (Nugroho \& Dahuri, 2012). Hal ini mengakibatkan adanya perubahan penggunaan lahan di arah pinggiran kota (pedesaan) dari lahan pertanian (non terbangun) menjadi lahan non pertanian (terbangun).

Menurut Xiao et al (2006) dan Firman (2009), ekspansi perkotaan ke wilayah pinggiran terkait dengan pengembangan ekonomi dilakukan untuk mengejar peningkatan perekonomian sehingga pada wilayah tersebut menjadi lebih berkembang. Di Indonesia sendiri, hal ini dipicu adanya investasi asing dan domestik terkait dengan pengembangan industri serta pembangunan infrastruktur (Firman, 2002). Salah satu contoh ekspansi perkotaan tersebut yaitu dengan pengembangan kota baru di wilayah pinggiran kota. Hal ini dilakukan agar berbagai kegiatan penduduk tidak terpusat atau terkonsentrasi pada pusat kota saja tetapi dapat menyebar merata ke wilayah lainnya. Oleh karena itu kedepannya perkembangan suatu kota dapat menyeluruh sehingga diharapkan perekonomian di wilayah pinggiran kota juga dapat meningkat.

Perkembangan kota bersifat dinamis yaitu akan selalu berubah dari waktu ke waktu tergantung dari masyarakatnya yang akan membuat suatu fungsi kota. Oleh karena itu perkembangan kota dapat dilihat dari perkembangan lahan terbangunnya sebagai akibat dari campur tangan manusia dalam membentuk fungsi kota itu sendiri. Perkembangan kota menurut Zahnd (1999) terdiri dari tiga cara yaitu:

a. Perkembangan horisontal yaitu suatu kota akan mengalami perkembangan ke arah luar yang dimana luasan kota akan bertambah tetapi ketinggian dan kuantitas lahan terbangun tetap.

b. Perkembangan vertikal yaitu suatu kota yang perkembangannya ke atas dimana terlihat dari ketinggian bangunan-bangunan yang bertambah tetapi wilayah pembangunan dan kuantitas lahan terbangunnya tetap.

c. Perkembangan interstisial yaitu suatu kota yang mengalami perkembangan ke arah dalam dimana kuantitas lahan terbangun bertambah tetapi wilayah pembangunan dan ketinggian bangunan tetap.

Menurut Yunus (2000) peningkatan kebutuhan ruang kekotaan baik sebagai tempat tinggal maupun sebagai fungsi-fungsi lainnya yang tidak diimbangi dengan ketersediaan ruang di dalam kota akan mengakibatkan perluasan ruang di wilayah pinggiran kota. Dikatakan invansion apabila terjadi peralihan lahan non urban menjadi lahan urban di pinggiran kota dan disebut sebagai urban sprawl apabila terjadi perembetan kenampakan fisik kota ke arah luar. Yunus juga menjelaskan bahwa urban sprawl terdiri dari tiga jenis yaitu:

a. Perembetan konsentris (concentric development atau low density continous development) yaitu perembetan areal perkotaan berjalan perlahan pada semua bagian luar kenampakan kota yang telah ada, kemudian akan membentuk morfologi kota yang relatif kompak tetapi perembetan yang ada tidak terlalu dipengaruhi oleh aspek transportasi.

b. Perembetan memanjang (ribbon development atau linier development) yaitu perembetan areal perkotaan tidak merata ke semua bagian kota tetapi paling terlihat pada sepanjang jalur transportasi sehingga terjadi peningkatan konversi lahan pertanian menjadi non pertanian.

c. Perembetan meloncat (leap frog development atau checker-board development) yaitu perembetan areal perkotaannya berpencar secara sporadis dan tumbuh pada tengah-tengah lahan pertanian sehingga menurut pakar lingkungan dianggap tidak efisien dan tidak memiliki nilai estetika.

Urbanisasi akibat dari peningkatan jumlah penduduk ini terjadi di Kota Semarang salah satunya yaitu Pembangunan kota baru di Semarang diawali dengan pembangunan Bukit Semarang Baru (BSB) oleh PT. Karyadeka Alam Lestari (PT. KAL) di Kecamatan Mijen. Kawasan ini dimaksudkan untuk dijadikan sebagai kota baru sebagai pendukung kehidupan masyarakat Kota Semarang. Kota baru sendiri merupakan sebuah komunitas yang memiliki luas tertentu dan telah melalui perencanaan menyeluruh serta dilakukan berbagai modifikasi yang memerlukan waktu lama dan diharapkan dapat melayani satu tujuan (Branch, 1985; Rodwin et al, 1981). Sujarto (1993) membagi kota baru menjadi dua yaitu kota baru penunjang (dikembangkan di dalam kota) serta kota baru mandiri (dikembangkan tersendiri pada suatu kota kecil). Pengertian kota baru lainnya yaitu menurut Harvey S. Perloff dan Neil C. Sandbery merupakan kota dengan ukuran yang relatif kecil yang dirancang dan direncanakan agar bisa mandiri sebab telah direncanakan 
penyediaan fasilitas kota sehingga memiliki peluang pekerjaan yang cukup serta fasilitas-fasilitas tersebut letaknya dapat terjangkau dan kota baru juga dapat menciptakan suasana lingkungan yang kondusif bagi masyarakat kota tersebut (Batudoka, 2005; Firman, 2004). Oleh karena itu dengan adanya kota baru dapat menciptakan keseimbangan dalam kehidupan masyarakat kota tersebut baik dalam memperoleh kesempatan kerja, hiburan dan rekreasi, industri, perdagangan dan fasilitas lainnya maupun keseimbangan dalam pekerjaan, pendapatan serta status sosial.

Dengan pembangunan Kota Baru BSB ini diharapkan dapat memecah konsentrasi penduduk yang hanya berada pada pusat Kota Semarang saja karena ke depannya sekitarnya dapat berkembang menjadi kawasan perkotaan. Kawasan BSB ini sebelumnya merupakan sebuah perkebunan karet yang sangat luas kemudian dijadikan perumahan serta rencananya akan terus dikembangkan berbagai macam fasilitas seperti perdagangan, industri, perkantoran, pendidikan dan sebagainya. Selain itu wilayah di sekitar BSB dulunya merupakan kawasan pedesaan yang terhitung masih sepi dan jauh dari pusat kota. Oleh karena itu BSB memberikan pengaruh yang besar baik bagi kawasan sekitar dan Kota Semarang itu sendiri, salah satunya yaitu adanya perubahan penggunaan lahan di sekitar kawasan tersebut yaitu dari non terbangun menjadi terbangun. Dalam Rencana Tata Ruang Wilayah (RTRW) Kota Semarang Tahun 2011-2031, Kecamatan Mijen diperuntukan sebagai perkantoran, perdagangan dan jasa serta permukiman. Oleh karena itu wilayah tersebut mengalami perkembangan perkotaan yang terlihat dari peningkatan luas lahan terbangun terlebih lagi setelah dikembangkannya pembangunan Kota Baru BSB.

Beberapa penelitian tentang perubahan penggunaan lahan telah banyak dilakukan sebelumnya. Seperti misalnya kajian mengenai perubahan penggunaan lahan setelah reformasi Cina di Beijing tahun 1992 hingga tahun 2008 (Du et al, 2014); deteksi perubahan penggunaan lahan di wilayah metropolitan Bandung pada tahun 1979, 2006 dan 2014 (Wijaya, 2015); kajian perubahan penggunaan lahan terbangun di Kota Semarang antara tahun 1991, 2001 dan 2008 (Handayani \& Rudiarto, 2014) dan kajian perubahan penggunaan lahan di wilayah sekitar pintu tol Ungaran pada tahun 2003, 2011 dan 2014 (Masykuroh \& Rudiarto, 2015). Akan tetapi, penelitian-penelitian tersebut hanya menguraikan bagaimana perubahan penggunaan lahan yang terjadi saja. Padahal perubahan penggunaan lahan pada suatu wilayah sangat erat kaitannya dengan perkembangan perkotaan yang terjadi di wilayah tersebut. Oleh karena itu penelitian ini penting dilakukan karena selain menganalisa bagaimana perubahan penggunaan lahan juga menganalisa bagaimana perkembangan perkotaan yang terjadi. Selain itu, penelitian di wilayah sekitar Bukit Semarang baru ini juga masih jarang dilakukan terlebih yang menganalisa mengenai perubahan penggunaan lahan dan perkembangan perkotaan. Salah satu penelitian yang mengambil lokasi di Bukit Semarang Baru yaitu yaitu penelitian Ariani \& Hadi (2016) dimana menganalisa mengenai sistem ekologi masyarakat yang dilihat dari aktivitas-aktivitas masyarakat di kawasan Bukit Semarang Baru. Dengan demikian, penelitian ini diharapkan dapat menambah kajian-kajian lain yang mengambil lokasi di sekitar kawasan Bukit Semarang Baru.

Dengan adanya permasalahan tersebut, selain menganalisa mengenai perubahan penggunaan lahan, penelitian ini juga dimaksudkan untuk mengetahui seperti apa bentuk perkembangan perkotaan yang terjadi di sekitar kawasan BSB apabila dilihat dari sudut pandang teoritis seperti yang diungkapkan dalam teori-teori perkembangan perkotaan. Dalam penelitian ini, perkembangan perkotaan dilihat dari perubahan penggunaan lahan antara tahun 2013 dan 2017 yang terjadi di sekitar kawasan BSB khususnya penggunaan lahan terbangun (industri, perdagangan dan jasa serta permukiman). Dengan demikian, penelitian ini dapat dijadikan sebagai pertimbangan dan masukan bagi stakeholder terkait dalam penentuan kebijakan penataan ruang wilayah dan kota.

\section{DATA DAN METODE}

2.1. Gambaran Umum Wilayah Penelitian

Wilayah penelitian ini berada di wilayah administrasi Kecamatan Mijen, kota Semarang tepatnya sekitar kawasan Bukit Semarang Baru yang terdiri dari Kelurahan Kedungpani, Kelurahan Jatibarang, Kelurahan Mijen, Kelurahan Jatisari, Kelurahan Purwosari, Kelurahan Tambangan, Kelurahan Pesantren, 
Kelurahan Wonolopo dan Kelurahan Ngadirgo. Secara geografis lokasi penelitian terletak pada $07^{\circ} 00^{\prime} 50^{\prime \prime}$ $07^{\circ} 05^{\prime} 32^{\prime \prime}$ Lintang Selatan dan $110^{\circ} 17^{\prime} 46^{\prime \prime} 110^{\circ} 21^{\prime} 50^{\prime \prime}$ Bujur Timur dengan batas wilayah meliputi:

- Sebelah Utara, berbatasan dengan Kecamatan Ngaliyan;

- Sebelah Timur, berbatasan dengan Kecamatan Gunungpati;

- Sebelah Selatan, berbatasan dengan Kelurahan Cangkiran, Kelurahan Bubakan dan Kelurahan Polaman;

Sebelah Barat, berbatasan dengan Kelurahan Wonoplumbon.

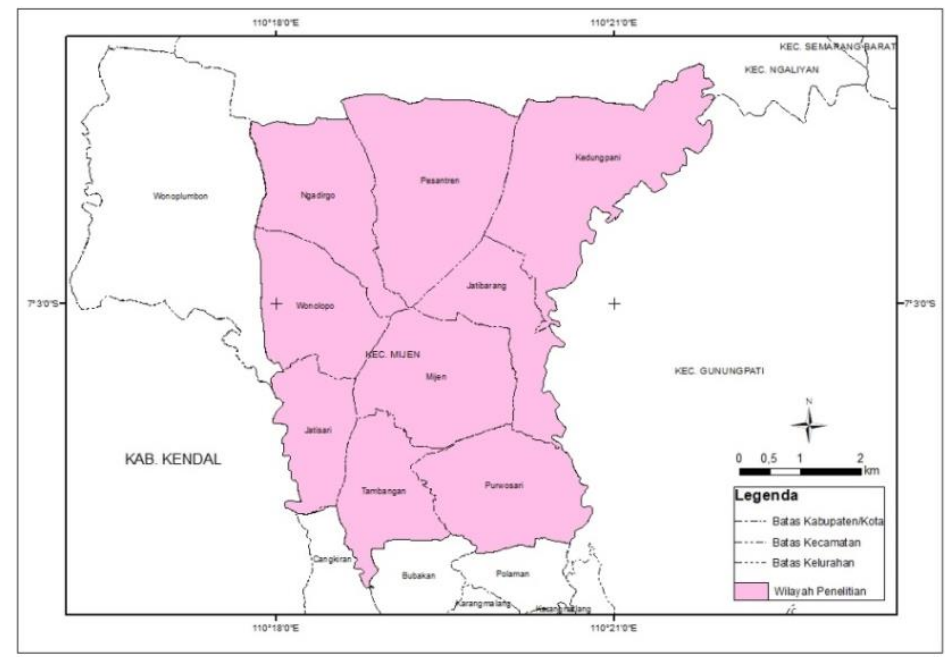

Sumber: Hasil Analisis, 2018

Gambar 1. Wilayah Penelitian

\subsection{Data dan Pendekatan Penelitian}

Jenis data yang akan digunakan dalam penelitian ini terdiri dari data primer dan sekunder. Data primer yang dibutuhkan dalam penelitian ini yaitu data survey penggunaan lahan di lokasi penelitian. Data sekunder yang dibutuhkan dalam penelitian ini yaitu: Citra satelit Kota Semarang tahun 2013 dan 2017 yang diperoleh dari citra DigitalGlobe, data dan peta penggunaan lahan tahun 2013 dan 2017, peta administrasi dan peta RTRW Kota Semarang Tahun 2011-2031, peta jaringan jalan serta peta Kawasan Bukit Semarang Baru.

Pendekatan penelitian yang digunakan dalam penelitian ini yaitu dengan pendekatan kuantitatif dengan pendekatan spasial. Hal ini didasarkan pada tulisan Creswell (2010) bahwa penelitian kuantitatif dirancang dengan menguji suatu teori untuk menjawab rumusan masalahnya. Dalam pelaksanaannya penelitian ini menggunakan pendekatan spasial yang bertujuan untuk melakukan pengolahan data spasial gambaran kondisi wilayah studi. Adapun tujuan penelitian ini untuk mengetahui perubahan penggunaan lahan di sekitar kawasan Bukit Semarang Baru secara time series pada tahun 2013 dan 2017 dengan pendekatan spasial.

\subsection{Teknik Analisis}

Dalam menganalisis penggunaan lahan ini dilakukan dengan cara mengklasifikasikan data penginderaan jauh berupa citra satelit melalui interpretasi foto udara atau citra satelit. Adapun unsur-unsur yang digunakan dalam interpretasi citra menurut Susanto (1994) dan Lillesand \& Kiefer (2000) terdiri dari:

1. Rona atau warna, yaitu tingkat kegelapan atau kecerahan suatu obyek pada citra seperti dari hitam ke putih atau sebaliknya. 
2. Bentuk, yaitu kerangka suatu obyek sehingga menjadi pembeda dari sebuah obyek dengan obyek lainnya yang dapat diidentifikasi dari bentuk masssa bangunan, maupun bentuk-bentuk fisik alam lainnya seperti jalan, sungai, kebun, hutan dan lainnya.

3. Ukuran, yaitu atribut suatu obyek berupa jarak, luas, tinggi, lereng dan volume.

4. Tekstur, terdiri dari tekstur kasar hingga halus yang mana merupakan hasil gabungan dari bentuk, ukuran, pola, banyangan serta rona.

5. Pola, yaitu ciri khas yang dapat mempermudah dalam menandai obyek-obyek buatan manusia.

6. Bayangan, pada satu sisi dapat memberikan gambaran dari sebuah obyek tetapi di sisi lain apabila obyek berada di bawah bayangan (sedikit memantulkan cahaya) menjadi sulit diamati pada citra.

7. Situs, yaitu lokasi suatu obyek dalam hubungannya dengan obyek lain sehingga mempermudah dalam interpretasi citra.

8. Asosiasi, yaitu hubungan atau keterkaitan antara obyek satu dengan obyek lainnya seperti halnya pada situs.

Berdasarkan hasil interpretasi citra dan pengecekan lapang didapatkan klasifikasi penggunaan lahan seperti danau/waduk, hutan, industri, lahan kosong, perdagangan dan jasa, permukiman, pertanian serta Tempat Pembuangan Akhir (TPA). Dari data penggunaan lahan tersebut, selanjutnya dianalisis perubahan penggunaan lahan di sekitar kawasan BSB selama tahun 2013-2017 dengan Sistem Informasi Geografis (SIG) menggunakan operasi tumpang tindih (overlay) pada peta penggunaan lahan tahun 2013, dan 2017. Selain itu juga dianalisis perkembangan perkotaan yang terjadi di sekitar kawasan BSB tahun 2013-2017 yaitu dengan mengidentifikasi penggunaan lahan terbangun secara spasial dengan berdasarkan teori-teori yang telah dikaji.

\section{HASIL DAN PEMBAHASAN}

\subsection{Analisis Penggunaan Lahan}

Dari hasil dari interpretasi digital, penggunaan lahan dapat diklasifikasikan menjadi delapan jenis yaitu danau/waduk, hutan, industri, lahan kosong, perdagangan dan jasa, permukiman, pertanian dan Tempat Pembuangan Akhir (TPA). Setelah dilakukan interpretasi dapat diketahui luas masing-masing penggunaan lahan di sekitar kawasan BSB pada tahun 2013 dan 2017 yang ditunjukkan pada Tabel 1 dan Gambar 2.

Tabel 1. Luas Penggunaan Lahan tahun 2013 dan 2017 (Hasil Analisis, 2018)

\begin{tabular}{|c|c|c|c|c|c|}
\hline \multirow[b]{2}{*}{ No } & \multirow{2}{*}{$\begin{array}{c}\text { Jenis Penggunaan } \\
\text { Lahan }\end{array}$} & \multicolumn{2}{|c|}{ Tahun 2013} & \multicolumn{2}{|c|}{ Tahun 2017} \\
\hline & & $\begin{array}{c}\text { Luas } \\
\text { (Hektar) }\end{array}$ & $\begin{array}{c}\text { Persentase } \\
\text { Luas }\end{array}$ & $\begin{array}{c}\text { Luas } \\
\text { (Hektar) }\end{array}$ & $\begin{array}{c}\text { Persentase } \\
\text { Luas }\end{array}$ \\
\hline 1 & danau/waduk & 34,95 & $0,92 \%$ & 71,40 & $1,87 \%$ \\
\hline 2 & hutan & 443,13 & $11,61 \%$ & 443,13 & $11,61 \%$ \\
\hline 3 & industri & 98,43 & $2,58 \%$ & 113,40 & $2,97 \%$ \\
\hline 4 & lahan kosong & 3,97 & $0,10 \%$ & 26,38 & $0,69 \%$ \\
\hline 5 & perdagangan dan jasa & 255,25 & $6,69 \%$ & 260,61 & $6,83 \%$ \\
\hline 6 & permukiman & 675,91 & $17,71 \%$ & 758,16 & $19,87 \%$ \\
\hline 7 & pertanian & $2.276,16$ & $59,65 \%$ & $2.114,71$ & $55,42 \%$ \\
\hline 8 & TPA & 27,78 & $0,73 \%$ & 27,78 & $0,73 \%$ \\
\hline & Total & $3.815,57$ & $100,00 \%$ & $3.815,57$ & $100,00 \%$ \\
\hline
\end{tabular}

Sumber: Hasil Analisis, 2018

Pada tahun 2013 dan 2017 lahan di sekitar kawasan BSB didominasi oleh penggunaan lahan pertanian yang luasnya mencapai lebih dari 50\% total penggunaan lahan. Penggunaan lahan pertanian memiliki luas paling besar karena sebelum dilaksanakan pengembangan kawasan BSB wilayah ini merupakan perkebunan karet. Selain itu, wilayah ini juga merupakan wilayah pinggiran Kota Semarang yang 
Oktinova, Rudiarto/ Jurnal Pembangunan Wilayah dan Kota, Vol.15, No.4, 2019, 262-276 Doi: https://doi.org/10.14710/pwk.v15i4.21534

didominasi penggunaan lahan pedesaan seperti misalnya sawah. Penggunaan lahan pada urutan berikutnya yaitu permukiman dan hutan. Perdagangan dan jasa menempati urutan keempat dan industri pada urutan kelima. Urutan penggunaan lahan berikutnya yaitu danau/waduk, TPA serta penggunaan lahan dengan luas terkecil yaitu lahan kosong.

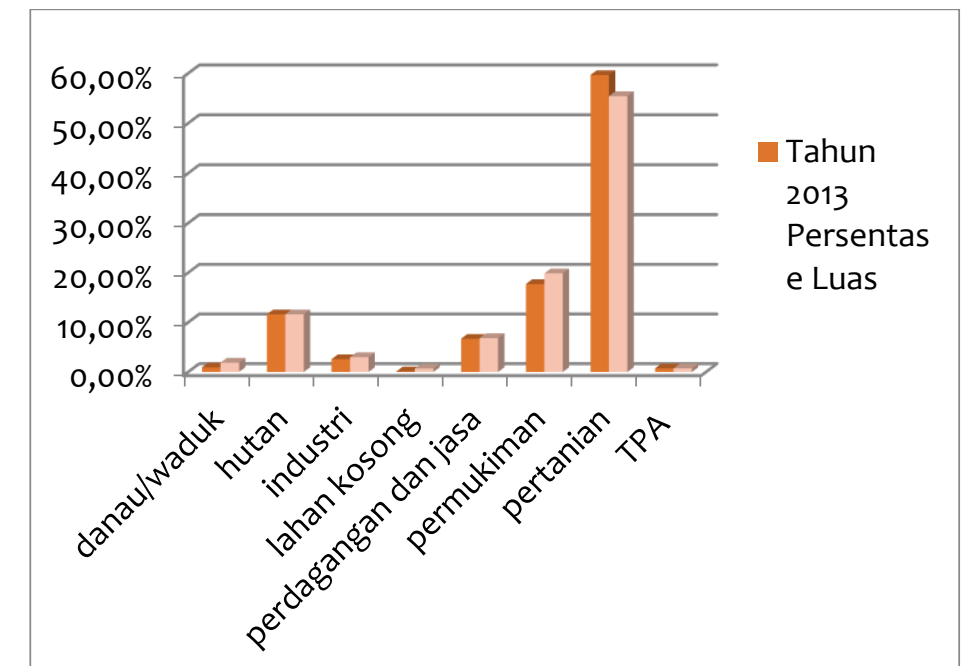

Sumber: Hasil Analisis, 2018

Gambar 2. Diagram Persentase Luas Penggunaan Lahan Tahun 2013 - Tahun 2017

Persebaran penggunaan lahan tahun 2013 dan 2017 untuk lebih jelasnya ditunjukkan pada Gambar 3.

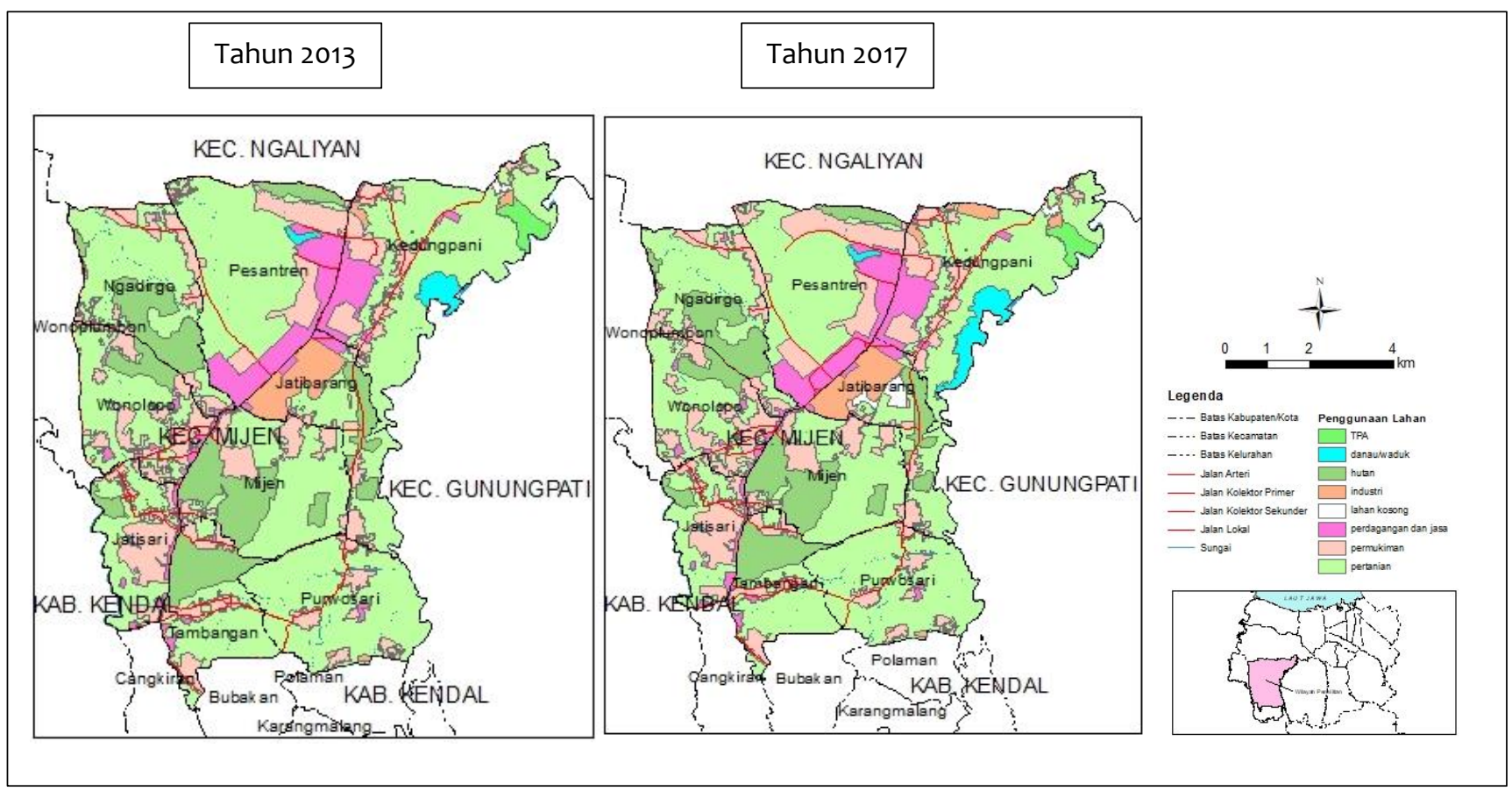

Sumber: Hasil Analisis, 2018

Gambar 3. Peta Penggunaan Lahan Tahun 2013 dan Tahun 2017 
Berdasakan Gambar 3, persebaran penggunaan lahan pada tahun 2013 untuk jenis penggunaan lahan danau/waduk berada pada tiga kelurahan yaitu dua buah danau buatan yang dibangun oleh perumahan Bukit Semarang Baru di Kelurahan Jatisari ( $0,80 \mathrm{ha}$ ) dan Pesantren (6,67 ha) serta satu buah waduk buatan bernama Waduk Jatibarang yang dibangun oleh Kementerian Pekerjaan Umum yang berada pada Kelurahan Kedungpani (27,48 ha). Pada penggunaan lahan hutan sebagian besar berada pada Kelurahan Mijen (131,80 ha) dan lahan hutan dengan luas terkecil berada pada Kelurahan Jatisari (12,83 ha). Hutan yang berada di sekitar kawasan BSB tersebut berupa hutan produksi tetap. Penggunaan lahan industri sebagian besar berada pada Kelurahan Jatibarang $(84,19 \mathrm{ha}$ ) berupa taman industri yang dikembangkan oleh perumahan Bukit Semarang Baru dan lahan industri dengan luas terkecil pada Kelurahan Purwosari (2,70 ha). Penggunaan lahan kosong berada pada Kelurahan Jatibarang (3,97 ha) yang berupa satu area kosong yang belum dimanfaatkan.

Penggunaan lahan perdagangan dan jasa tersebar di seluruh kelurahan dan sebagian besar berada pada Kelurahan Pesantren (124,06 ha) dan dengan luas terkecil berada pada Kelurahan Purwosari (3,77 ha). Pihak pengembang dari perumahan Bukit Semarang Baru ini akan mengembangkan satu kawasan Central Bussiness Distric (CBD) yang berada pada Kelurahan Pesantren dan Kedungpani dimana kawasan ini merupakan pusat dari kegiatan perdagangan dan jasa.

Penggunaan lahan pemukiman tersebar di seluruh kelurahan dimana sebagian besar berada pada Kelurahan Kedungpani (106,38 ha) dan Pesantren (102,96 ha). Pada kedua kelurahan ini dibangun perumahan-perumahan besar (Grha Taman Bunga, Grha Taman Pelangi, Beranda Bali, Puri Arga Golf serta Graha Taman Nirwana) oleh pengembang dari Bukit Semarang Baru sehingga terlihat mendominasi pada wilayah tersebut. Penggunaan lahan permukiman dengan luas terkecil berada pada Kelurahan Jatibarang (32,94 ha).

Penggunaan lahan pertanian tersebar di seluruh wilayah dimana sebagian besar berada pada pada Kelurahan Kedungpani (465,42 ha) dengan didominasi perkebunan karet milik perumahan Bukit Semarang Baru. Lahan pertanian dengan luas terkecil berada pada Kelurahan Jatisari (123,13 ha). Penggunaan lahan TPA berada pada Kelurahan Kedungpani (27,78 ha) berupa TPA Jatibarang yang dikelola oleh Pemerintah Kota Semarang.

Persebaran penggunaan lahan pada tahun 2017 untuk jenis penggunaan lahan danau/waduk dengan luas terbesar masih berada pada Kelurahan Kedungpani (63,93 ha) dan luas terkecil pada Kelurahan Jatisari ( $0,80 \mathrm{ha}$ ). Penggunaan lahan hutan dengan luas terbesar juga masih berada pada Kelurahan Mijen (131,80 ha) dan dengan luas terkecil berada pada Kelurahan Jatisari (12,83 ha). Penggunaan lahan industri dengan sebagian besar berada pada Kelurahan Jatibarang $(84,19 \mathrm{ha})$ dan dengan luas terkecil pada Kelurahan Purwosari (2,70 ha). Penggunaan lahan lahan kosong pada tahun 2017 ini mengalami perubahan dimana sebagian besar berada pada Kelurahan Jatibarang (21,89 ha).

Penggunaan lahan perdagangan dan jasa sebagian besar masih berada pada Kelurahan Pesantren (126,40 ha) dan luas terkecil pada Kelurahan Purwosari (3,77 ha). Penggunaan lahan pemukiman dengan luas terbesar berada pada Kelurahan Pesantren (139,80 ha) dan permukiman dengan luas terkecil berada pada Kelurahan Jatibarang (33,48 ha). Penggunaan lahan pertanian dengan luas terbesar yaitu pada Kelurahan Kedungpani (404,91 ha) dan terkecil pada Kelurahan Jatibarang (109,01 ha). Penggunaan lahan TPA pada tahun 2017 juga masih mendominasi pada Kelurahan Kedungpani (27,78 ha).

\subsection{Analisis Perubahan Penggunaan Lahan}

Analisis perubahan penggunaan lahan di sekitar kawasan BSB ini dilakukan dengan membandingkan penggunaan lahan pada tahun 2013 dan tahun 2017. Matriks perubahan penggunaan lahan antara tahun 2013 dan tahun 2017 dapat dilihat ada Tabel 2.

Berdasarkan Tabel 2, lahan antara tahun 2013 dan tahun 2017 penggunaan lahan yang berubah paling besar luasannya yaitu pada penggunaan lahan pertanian. Penggunaan lahan ini mengalami perubahan menjadi danau/waduk ( $36,45 \mathrm{ha})$, industri ( $14,98 \mathrm{ha})$, lahan kosong (22,41 ha), perdagangan dan jasa $(2,78$ ha) dan permukiman (84,84 ha). Selain pertanian, penggunaan lahan lainnya yang mengalami perubahan yaitu pada penggunaan lahan permukiman yang mengalami perubahan menjadi perdagangan dan jasa. 
Penggunaan lahan TPA dan hutan tidak mengalami perubahan luasan berarti dalam pengembangan BSB ini tidak mempengaruhi luasan kawasan hutan sebagai kawasan lindung di wilayah sekitarnya. Luasan perubahan pada masing-masing penggunaan lahan dapat disimpulkan pada Tabel 3.

Tabel 2. Matriks Perubahan Penggunaan Lahan tahun 2013 dan 2017

\begin{tabular}{|c|c|c|c|c|c|c|c|c|c|c|}
\hline \multirow{2}{*}{\multicolumn{2}{|c|}{$\begin{array}{l}\text { Jenis } \\
\text { Penggunaan } \\
\text { Lahan }\end{array}$}} & \multicolumn{9}{|c|}{ Luas Perubahan Penggunaan Lahan Tahun 2013-2017 (hektar) } \\
\hline & & $\begin{array}{l}\text { danau/ } \\
\text { waduk }\end{array}$ & hutan & industri & $\begin{array}{c}\begin{array}{c}\text { lahan } \\
\text { kosong }\end{array} \\
\end{array}$ & $\begin{array}{c}\text { Tahun } 2017 \\
\text { perdagangan } \\
\text { dan jasa }\end{array}$ & permukiman & pertanian & TPA & $\begin{array}{c}\text { Total } \\
\text { Tahun } \\
2013 \\
\end{array}$ \\
\hline \multirow{9}{*}{ 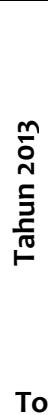 } & $\begin{array}{l}\text { danau/ } \\
\text { waduk }\end{array}$ & 34,95 & 0,00 & 0,00 & 0,00 & 0,00 & 0,00 & 0,00 & 0,00 & 34,95 \\
\hline & hutan & 0,00 & 443,13 & 0,00 & 0,00 & 0,00 & 0,00 & 0,00 & 0,00 & 443,13 \\
\hline & industri & 0,00 & 0,00 & 98,43 & 0,00 & 0,00 & 0,00 & 0,00 & 0,00 & 98,43 \\
\hline & lahan kosong & 0,00 & 0,00 & 0,00 & 3,97 & 0,00 & 0,00 & 0,00 & 0,00 & 3,97 \\
\hline & $\begin{array}{l}\text { perdagangan } \\
\text { dan jasa }\end{array}$ & 0,00 & 0,00 & 0,00 & 0,00 & 255,25 & 0,00 & 0,00 & 0,00 & 255,25 \\
\hline & permukiman & 0,00 & 0,00 & 0,00 & 0,00 & 2,59 & 673,32 & 0,00 & 0,00 & 675,91 \\
\hline & pertanian & 36,45 & 0,00 & 14,98 & 22,41 & 2,78 & 84,84 & $2.114,70$ & 0,00 & $2.276,16$ \\
\hline & TPA & 0,00 & 0,00 & 0,00 & 0,00 & 0,00 & 0,00 & 0,00 & 27,78 & 27,78 \\
\hline & otal Tahun 2017 & 71,40 & 443,13 & 113,40 & 26,38 & 260,61 & 758,16 & $2.114,71$ & 27,78 & $3.815,57$ \\
\hline
\end{tabular}

Sumber: Hasil Analisis, 2018

Tabel 3. Perubahan Penggunaan Lahan Tahun 2013 - Tahun 2017

\begin{tabular}{llrr}
\hline \multirow{2}{*}{ No } & Jenis Penggunaan Lahan & \multicolumn{2}{c}{$\begin{array}{c}\text { Perubahan Luas Penggunaan Lahan } \\
\text { hektar }\end{array}$} \\
\hline 1 & danau/waduk & 36,45 & $104,28 \%$ \\
2 & hutan & 0,00 & $0,00 \%$ \\
3 & industri & 14,98 & $15,22 \%$ \\
4 & lahan kosong & 22,41 & $564,46 \%$ \\
5 & perdagangan dan jasa & 5,37 & $2,10 \%$ \\
6 & permukiman & 82,25 & $12,17 \%$ \\
7 & pertanian & $-161,45$ & $-7,09 \%$ \\
8 & TPA & 0,00 & $0,00 \%$ \\
\hline
\end{tabular}

Sumber: Hasil Analisis, 2018

Berdasarkan Tabel 3 dapat disimpulkan bahwa di sekitar kawasan BSB pada penggunaan lahan danau/waduk, industri, lahan kosong, perdagangan dan jasa serta permukiman telah mengalami peningkatan luasan. Akan tetapi pada penggunaan lahan pertanian mengalami penurunan sebesar 161,45 ha. Hal ini mengindikasikan bahwa di sekitar kawasan BSB telah mengalami perubahan penggunaan lahan dari penggunaan lahan pertanian menjadi lahan non pertanian. Pada penggunaan danau/waduk mengalami peningkatan sebesar 36,45 ha karena pada wilayah ini antara tahun 2013 sampai dengan tahun 2017 sedang dilaksanakan pembangunan waduk Jatibarang oleh Kementerian Pekerjaan Umum. Penggunaan lahan industri mengalami peningkatan luasan sebesar 14,98 ha karena pada wilayah ini juga sedang dilaksanakan pembangunan kawasan industri. Tahun 2017 penggunaan lahan kosong mengalami peningkatan yang cukup besar dari tahun 2013 yaitu sebesar 22,41 ha. Luasan penggunaan lahan perdagangan dan jasa meningkat 5,37 ha dan permukiman juga meningkat 82,25 ha karena seiring dengan pengembangan kota baru BSB sehingga di wilayah ini dibangun perumahan-perumahan dan kawasan perdagangan dan jasa untuk mendukung tercapainya kota baru tersebut. Persebaran perubahan penggunaan lahan tahun 20132017 dapat dilihat pada Gambar 4. 
Oktinova, Rudiarto/ Jurnal Pembangunan Wilayah dan Kota, Vol.15, No.2, 2019, 262-276

Doi: https://doi.org/10.14710/pwk.v15i4.21534

\subsection{Analisis Perkembangan Perkotaan}

Pada penelitian ini analisis perkembangan perkotaan di sekitar kawasan BSB dilihat dari perkembangan penggunaan lahan terbangun yang terdiri dari perdagangan dan jasa, industri dan permukiman dari tahun 2013 dan 2017. Luas penggunaan lahan terbangun di sekitar kawasan BSB pada tahun 2013 dan 2017 ditunjukkan pada Tabel 4.

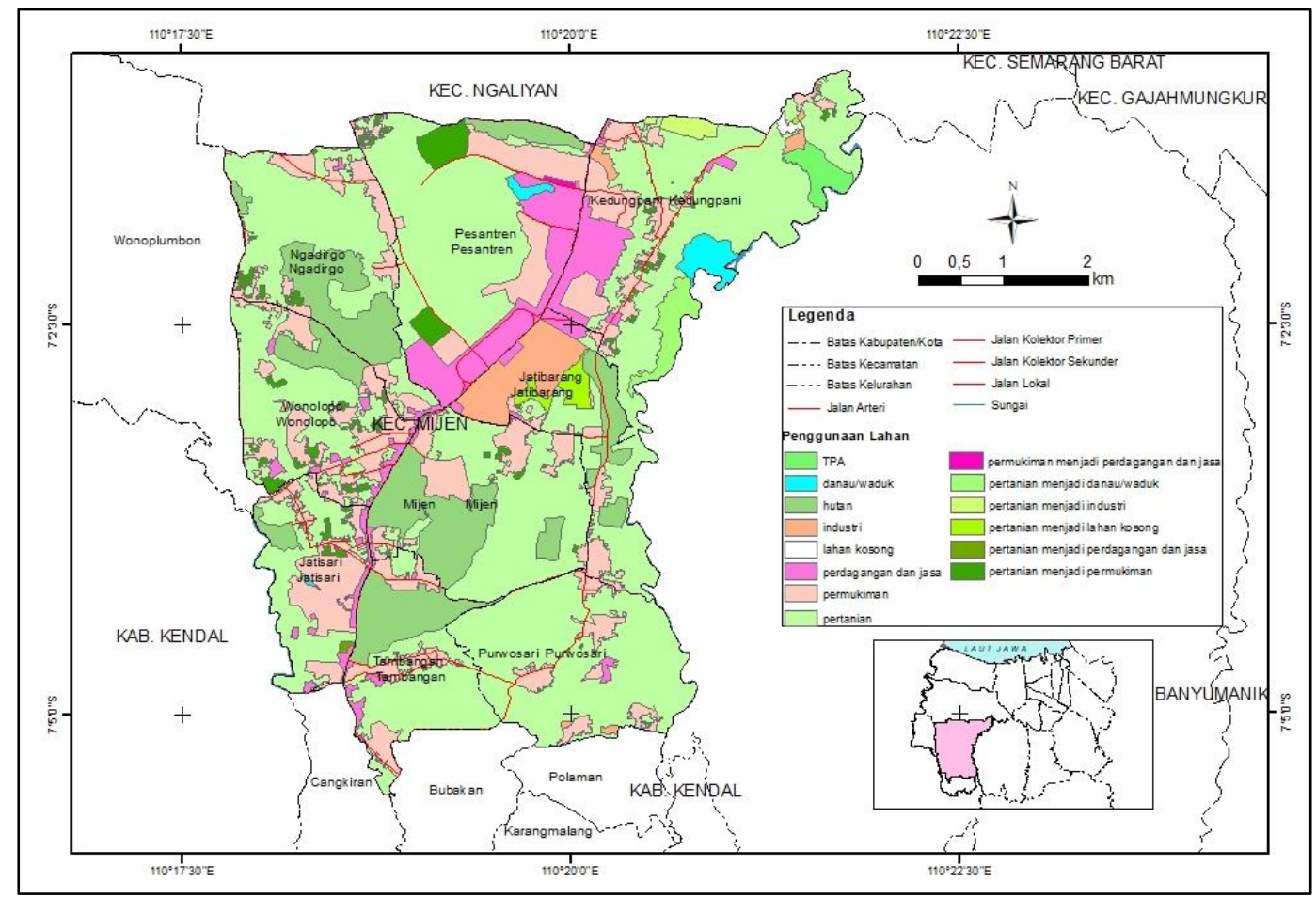

Sumber: Hasil Analisis, 2018

Gambar 4. Peta Perubahan Penggunaan Lahan Tahun 2013 - Tahun 2017

Tabel 4. Luas Penggunaan Lahan Terbangun Tahun 2013 dan Tahun 2017

\begin{tabular}{|c|c|c|c|c|}
\hline \multirow[t]{2}{*}{ No } & \multirow[t]{2}{*}{ Jenis Penggunaan Lahan Terbangun } & \multicolumn{2}{|c|}{$\begin{array}{c}\text { Luas Penggunaan } \\
\text { Lahan Terbangun } \\
\text { (hektar) }\end{array}$} & \multirow{2}{*}{$\begin{array}{c}\text { Persentase } \\
\text { Perubahan Luas Penggunaan } \\
\text { Lahan Terbangun } \\
\text { Tahun 2013-2017 }\end{array}$} \\
\hline & & $\begin{array}{c}\text { Tahun } \\
2013 \\
\end{array}$ & $\begin{array}{c}\text { Tahun } \\
2017\end{array}$ & \\
\hline 1 & industri & 98,43 & 113,40 & $15 \%$ \\
\hline 2 & perdagangan dan jasa & 255,25 & 260,61 & $2 \%$ \\
\hline 3 & permukiman & 675,91 & 758,16 & $12 \%$ \\
\hline Total & I Luas Penggunaan Lahan Terbangun & $1.029,58$ & $1.132,17$ & $10 \%$ \\
\hline
\end{tabular}

Sumber: Hasil Analisis, 2018

Berdasarkan Tabel 4, dari luas wilayah penelitian sebesar 3.815,57 hektar, penggunaan lahan terbangun di wilayah ini pada tahun 2013 dan 2017 masih kurang dari 30\% total luas wilayah. Hal ini terjadi karena sebelum dilaksanakan pengembangan kawasan BSB, wilayah ini merupakan wilayah pinggiran Kota Semarang yang masih berupa pedesaaan dengan didominasi penggunaan lahan pertanian (perkebunan karet dan persawahan). Akan tetapi, setelah dilaksanakan pengembangan kawasan BSB yang direncanakan untuk dijadikan sebagai sebuah kota baru, penggunaan lahan terbangun di sekitar kawasan BSB dari tahun ke tahun mengalami peningkatan. Peningkatan luasan lahan terbangun pada tahun 20132017 sebesar 102,59 ha (10\%). Dengan adanya peningkatan terhadap luasan lahan terbangun berarti terjadi 
penurunan terhadap luasan lahan non terbangun sehingga dapat dikatakan bahwa di wilayah penelitian ini telah terjadi perkembangan perkotaan seiring dengan adanya pengembangan kawasan BSB.

Perkembangan perkotaan di wilayah penelitian ini terjadi secara konsentris dengan memusat pada kawasan BSB itu sendiri. Perkembangan perkotaan yang ada secara horisontal cenderung ke arah luar pada seluruh bagiannya. Kawasan BSB menjadi pusat aktivitas di wilayah tersebut yang terlihat dari luasan penggunaan lahan perdagangan dan jasa terbesar berada di kawasan BSB, kemudian pada wilayah di sekitarnya dari tahun ke tahun juga mengalami penambahan luasan lahan terbangun. Lahan terbangun ini tidak hanya berada pada wilayah yang berdekatan dari kawasan BSB tetapi juga pada wilayah yang berada jauh dari kawasan BSB sehingga dapat dikatakan bahwa perkembangan perkotaan di wilayah ini penelitian terjadi menyebar pada seluruh bagiannnya. Seperti misalnya pada wilayah barat dari Kecamatan Ngadirgo dan Kecamatan Wonolopo, walaupun posisinya jauh dari BSB, tetapi pada wilayah ini juga terkena pengaruh dari pengembangan BSB. Wilayah yang sebelumnya merupakan lahan non terbangun mengalami perubahan menjadi lahan terbangun.

Pada perencanaan Pemerintah Kota Semarang sendiri menjadikan kawasan BSB ini sebagai kota baru untuk menampung arus urbanisasi yang cenderung ke pusat kota Semarang. Dengan demikian seluruh wilayah di sekitar kawasan BSB tersebut dapat ditingkatkan fungsinya dalam mendukung terciptanya kota baru tersebut. Perkembangan perkotaan di sekitar kawasan BSB dapat dilihat pada Gambar 5.

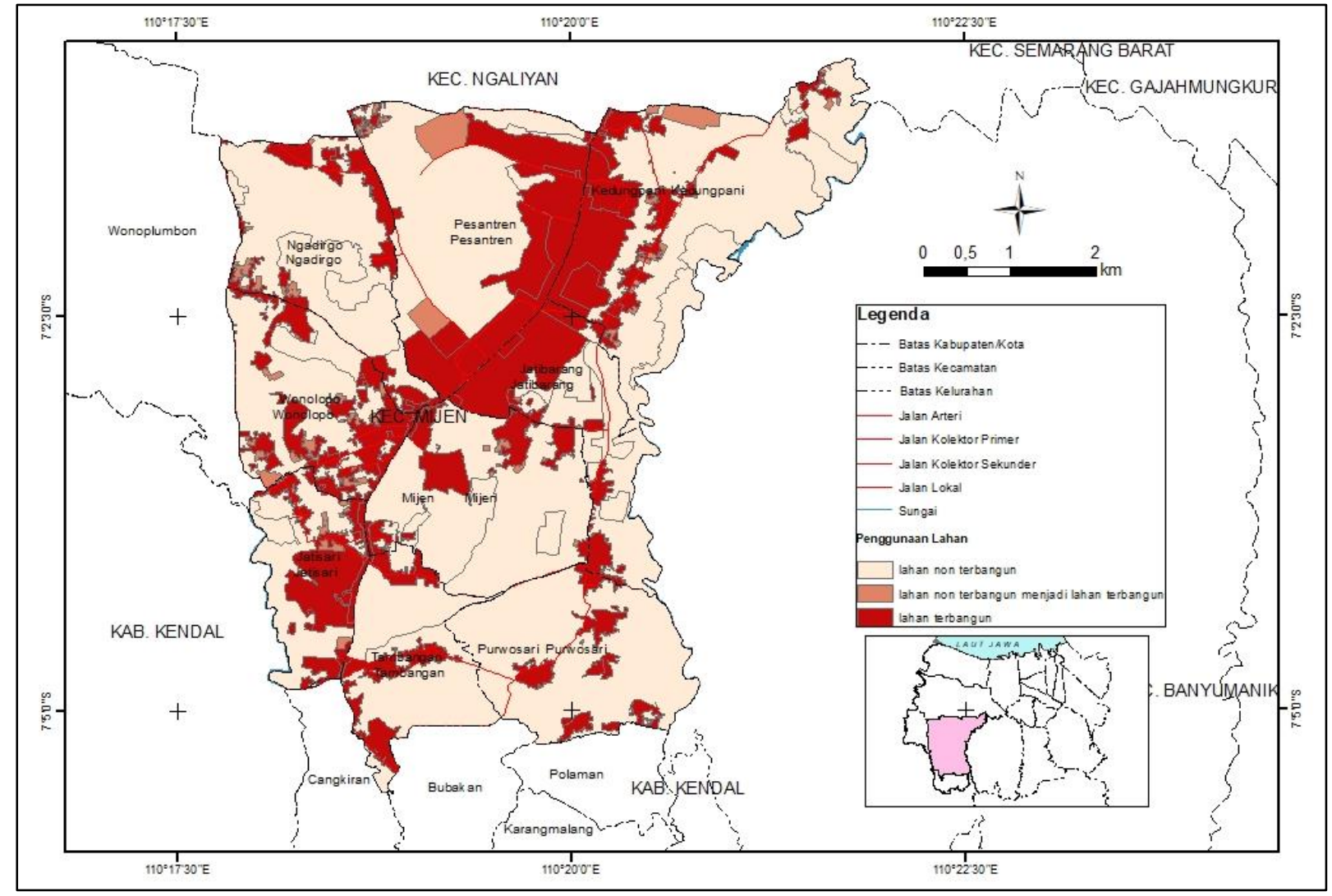

Sumber: Hasil Analisis, 2018

Gambar 5. Perkembangan Perkotaan Tahun 2013 - Tahun 2017

Melihat posisinya dari wilayah Kota Semarang, kawasan Bukit Semarang Baru ini terletak di Kecamatan Mijen yang merupakan wilayah pinggiran kota dimana pusat kota berada di Kecamatan Semarang Tengah. Dalam Rencana Tata Ruang Wilayah Kota Semarang Tahun 2010-2030, pada Kecamatan Mijen ini direncanakan sebagai sub pusat pelayanan kota yang didukung dengan adanya rencana 
pemanfaatan ruang sebagai kawasan perdagangan jasa skala sub kota. Selain itu di Kecamatan Mijen ini juga direncanakan pengembangan kawasan pendidikan, kawasan industri dan perumahan. Perencanaan tersebut diharapkan dapat memacu perkembangan daerah selatan dari Kota Semarang. Dengan demikian pembangunan kota baru kawasan Bukit Semarang Baru ini telah sesuai dengan perencanaan tata ruang yang ada dimana telah dikembangkan perumahan berskala besar yang dilengkapi fasilitas pendukung seperti perdagangan dan jasa, pendidikan dan industri.

Selain itu pada penelitian ini didapatkan hasil bahwa di sekitar kawasan BSB juga telah mengalami perkembangan perkotaan yang terlihat dari adanya peningkatan luas lahan terbangun seperti industri, perdagangan dan jasa serta permukiman. Pada penelitian Ariani dan Hadi (2016) juga dianalisis bahwa aktivitas masyarakat di di kawasan BSB ini tidak sepenuhnya dilakukan di kawasan pusat Kota Semarang saja tetapi juga dilakukan pada wilayah BSB dan sekitarnya yang masih dalam lingkup Kecamatan Mijen terutama pada aktivitas belanja. Aktivitas masyarakat dipengaruhi fasilitas yang ada pada suatu wilayah sehingga dengan adanya peningkatan penggunaan lahan industri, perdagangan dan jasa serta permukiman telah menarik masyarakat untuk beraktivitas di wilayah ini sehingga dapat memecah konsentrasi masyarakat di pusat kota saja. Hal ini mengindikasikan bahwa dengan adanya kawasan BSB ini, perkotaan Semarang sendiri juga telah mengalami perkembangan ke Kecamatan Mijen yang merupakan wilayah pinggian Kota Semarang.

\section{KESIMPULAN}

Berdasarkan hasil analisis, penggunaan lahan di sekitar kawasan BSB telah mengalami danau/waduk, industri, lahan kosong, perdagangan dan jasa, permukiman dan pertanian peningkatan luasan tetapi pada penggunaan lahan pertanian mengalami penurunan luasan. Perubahan penggunaan lahan terbesar terjadi pada penggunaan lahan pertanian menjadi permukiman. Pada penggunaan lahan TPA dan hutan tidak mengalami perubahan luas penggunaan lahannya. Hal ini berarti, di sekitar kawasan BSB telah mengalami perubahan penggunaan lahan khususnya dari lahan pertanian yang merupakan lahan non terbangun menjadi lahan terbangun.

Berdasarkan teori perkembangan perkotaan, pengembangan BSB sebagai sebagai kota baru di Semarang telah berpengaruh pada perkembangan perkotaan di sekitar kawasan tersebut yang terlihat dari peningkatan luasan penggunaan lahan terbangun pada wilayah penelitian ini. Penggunaan lahan terbangun yang meningkat paling besar yaitu pada permukiman sehingga hal ini sejalan dengan kebijakan pemerintah dalam Rencana Tata Ruang Wilayah Kota Semarang Tahun 2011-2031 yang menjadikan wilayah Mijen sebagai kawasan permukiman. Perkembangan perkotaan yang terjadi di sekitar kawasan BSB sesuai dengan teori Zahnd dan Yunus yaitu secara horisontal yang memusat pada kawasan BSB sebagai kawasan perkotaan di wilayah Mijen kemudian berkembang menyebar ke seluruh bagian wilayah sekitarnya sehingga dapat dikatakan bahwa tidak hanya kawasan BSB saja yang berkembang tetapi wilayah sekitarnya juga turut mengalami perkembangan.

\section{PERNYATAAN RESMI}

Terima kasih kepada seluruh pihak yang telah memberi kesempatan dan dukungan pembiayaan dalam menyelesaikan penelitian ini, khususnya Pusbindiklatren Bappenas dan Kementerian Agraria dan Tata Ruang.

\section{REFERENSI}

Adisasmita, R. (2014). Ekonomi Tata Ruang Wilayah. Yogyakarta: Penerbit Graha Ilmu.

Ariani, N.,vM., \& Hadi, S., P. (2016). "Sistem Sosial Ekologi Masyarakat Pada Kawasan Kota Baru Mandiri Bukit Semarang Baru (BSB)". Jurnal Pembangunan Wilayah dan Kota, Vol. 1 (2), pp. 210-223. https://doi.org/10.14710/pwk.v12i2.12896 
Oktinova, Rudiarto/ Jurnal Pembangunan Wilayah dan Kota, Vol.15, No.4, 2019, 262-276

Doi: https://doi.org/10.14710/pwk.v15i4.21534

Aryany, P., A., \& Pradoto, W. (2014). “Perubahan Penggunaan Lahan Di Kawasan Sekitar Bukit Semarang Baru”. Jurnal Teknik PWK, Vol. 3, No. 1.

Antrop, M. (2004). "Landscape change and the urbanization process in Europe". Journal of Landscape and Urban Planning, Vol. 67, pp. 9-26. https://doi.org/10.1016/S0169-2046(03)00026-4

Batudoka, Z. (2005). “Kota Baru dan Aspek Permukiman Mendepan”. Jurnal SMARTek, Vol. 3, No. 1, hal. 2736.

Branch, M.,C. (1985). Comprehensive City Planning: Introduction \& Explanation. The Planners Press of the American Planning Association.

Chapin, F., S., \& Kaiser, E. J. (1979). Urban Land Use Planning. Third Edition. Chicago: University of Illinois Press.

Champion, T. (2001). Urbanization, Suburbanization, Counterurbanization and Reurbanization. Handbook of Urban Studies. SAGE Publication Ltd.

Creswell, J.W. 2010. Research Design: Pendekatan Kualitatif, Kuantitatif dan Mixed. Yogyakarta: PT Pustaka Pelajar.

Du, J., Thill, J., Peiser, R. B., \& Feng, C. (2014). "Urban Land Market and Land-Use Changes in Post-Reform China : A Case Study of Beijing". Journal of Landscape and UrbanPlanning, Vol. 124, pp. $118-128$. https://doi.org/10.1016/j.landurbplan.2014.01.012

Firman, T. 2002. "Urban Development in Indonesia, 1990-2001: from The Boom to The Early Reform Era Through The Crisis". Journal of Habitat International, Vol. 26, pp. 229-249. https://doi.org/10.1016/S0197-3975(01)00045-5

Firman, T. 2004. "New Town Development in Jakarta Metropolitan Region: A Perspesctive of Spatial Segregation". Journal of Habitat International, Vol. 28, pp. 349-368. https://doi.org/10.1016/S0197-3975(03)00037-7

Firman, T. 2009. "The Continuity and Change in Megaurbanization in Indonesia : A Survey of Jakarta - Bandung Region ( $\mathrm{Jbr}$ ) Development". Journal of Habitat International, Vol. 33(4), pp. 327-339. https://doi.org/10.1016/j.habitatint.2008.08.005

Gu, W., Guo, J., Fan, K., \& Chan, E.H.W. (2016). "Dynamic Land Use Change and Sustainable Urban Development in a Thirdtier City within Yangtze Delta”. Journal of Procedia Environmental Sciences, Vol. 36, pp. 98-105. https://doi.org/10.1016/j.proenv.2016.09.019

Handayani, W., \& Rudiarto, I. (2014). "Dynamics of Urban Growth in Semarang Metropolitan - Central Java: An Examination Based on Built-Up Area and Population Change”. Journal of Geography and Geology, Vol. 6 (4), pp. 80-87. https://doi.org/10.5539/jgg.v6n4p80

Kaiser, E.J., Godschalk, D.R., Chapin, F.S. (1995). Urban Land Use Planning. Fourth Edition. Chicago: University of Illinois Press.

Lambin, E. F., Turner, B. L., Geist, H. J., Agbola, S. B., Angelsen, A., Folke, C., ... Veldkamp, T. A. (2001). "The Causes of Landuse and Landcover Change : Moving Beyond The Myths". Journal of Global Environment Change, Vol. 11, pp. 261-269. https://doi.org/10.1016/So959-3780(01)00007-3

Lillesand, T.M., Kiefer, R.W. (2000). Remote Sensing and Image Interpretation. New York: John Wiley. https://doi.org/10.1002/esp.267

Masykuroh, D., K., \& Rudiarto, I. (2016). "Kajian Perubahan Penggunaan Lahan dan Harga Lahan di Wilayah Sekitar Pintu Tol Ungaran”. Jurnal Tata Loka, Vol. 18 (1), pp 53-66. https://doi.org/10.14710/tataloka.18.1.58-70

Nasucha, C. (1995). Politik Ekonomi Pertanahan dan Struktur Perpajakan Atas Tanah. Jakarta: Penerbit Megapoin.

Nugroho, I. \& Dahuri, R. (2012). Pembangunan Wilayah Perspektif Ekonomi, Sosial dan Lingkungan. Jakarta: Penerbit LP3ES.

Rodwin, L., Evans, H., Hollister, R., Lynch, K., Southworth, M., Susskind, L. 1981. Cities and City Planning. New York: Plenum Press. https://doi.org/10.1007/9781468410891

Sharif, M.S. and Esa, A. J. (2014). "Dynamics Of Land Price and Land Use Change: A Case of Savar Municipality, Bangladesh". Journal of South Asian Studies, Vol. 2(1), pp. 83-89.

Sujarto, D. 1993. "Perkembangan Kota Baru”. Jurnal PWK, No. 9. Jurusan Teknik Planologi FTSP ITB.

Susanto. (1994). Penginderaan Jauh Jilid 2. Yogyakarta: Gadjah Mada University Press.

Wijaya, N. (2015). “Deteksi Perubahan Penggunaan Lahan Dengan Citra Landsat dan Sistem Informasi Geografis: Studi Kasus Di Wilayah Metropolitan Bandung, Indonesia”. Journal of Geomatics and Planning, Vol. 2, pp82-92. https://doi.10.14710/geoplanning.2.2.82-92

Xiao, J., Shen, Y., Ge, J., Tateishi, R., Tang, C., Liang, Y., \& Huang, Z. (2006). "Evaluating Urban Expansion and Land Use Change in Shijiazhuang, China, by Using Gis and Remote Sensing”. Journal of Landscape and Urban Planning, Vol. 75(1-2), pp. 69-80. https://doi.org/10.1016/j.landurbplan.2004.12.005

Yunus, H.S. (2000). Struktur Tata Ruang Kota. Yogyakarta: Penerbit Pustaka Pelajar.

Zahnd, M. (1999). Perancangan Kota Secara Terpadu. Yogyakarta: Penerbit Kanisius. 